\title{
Strategic alliances in the European industries of the Third Industrial Revolution
}

\begin{abstract}
The dimension of the alliances has compelled experts to revise their preconceptions about the internationalization of companies and to include this strategy in their models as Uppsala model was forced to acknowledge. This article focuses on one of the alliances forged in Europe, very deviated from the practices of the majority because it was a company with exclusively European partners. It adopts the perspective of a peripheral country (Spain) in the global economy and from the special status of at least one of the partners in a monopoly. Finally, the article follows case study methodology, which aims to delve into the complexity of the processes and the phenomena at hand. The article responds to the need for an alternative approach to industry analysis that is particularly important for technology-based industries and the most turbulent high-tech industries. The first section examines the creation of European Silicon Structures as a strategic alliance in the European semiconductor industry. Parts two and three look at the case of Spain and the role of demand using the example of Telefonica. Conclusions are presented in the final section.
\end{abstract}

Keywords: Strategic Alliances; Microelectronics; Technology Transfer; Telefonica

Corresponding author. E-mail: angel.calvo@ub.edu

Received 6 April 2016 - Accepted 17 April 2016

This is an Open Access article distributed under the terms of the Creative Commons Attribution-Non-Commercial-No Derivatives License (http://creativecommons.org/licenses/by-nc-nd/4.0/), which permits non-comercial re-use and distribution, provided the original work is properly cited, and is not altered or transformed in any way. 


\section{Introduction}

Global strategic alliances are cooperative business arrangements between actual or potential competitor firms from several countries involving joint ventures for short-term contractual agreements around a particular problem (such as developing a new product). From a managerial perspective, the strategic objectives of these alliances are to enter into a foreign market, share the fixed costs and risks associated with the development of new products and processes, assist the inter-firm transfer of complementary skills, and establish technical standards (Hill, Jones, and Schilling 2016). In a more general framework, firms find in international alliances the flexibility to respond to changing market conditions and effective paths for enlarging the scale of operations together with green field investment and mergers and acquisitions (M\&As). The driving forces behind them embrace cost economizing in production and $\mathrm{R} \& \mathrm{D}$, strengthening market presence, and accessing intangible assets.

During the last two decades of the $20^{\text {th }}$ century, the intensification of competition in open markets forced companies to adopt measures that would enable them to meet the new challenges in optimal conditions. One of the answers was to develop international strategic alliances, which became standard practice in the struggle for competitiveness, but with very different results. Sectoral and geographical components influenced the configuration of the alliances in such a way that in some industries, such as high-tech industries, they slightly outnumbered the amount of M\&As and in the case of Europe, on which this article focuses, alliances established with the United States predominated over inter-European alliances.

The dimension of the phenomenon has forced experts to revise their preconceptions about the internationalization of companies and to include this strategy in their models; this was the case of the Uppsala model, initially very conditioned by its allegiance to Northern European 
industrial processes. Joining Dunning's (2001) OLI paradigm, it acknowledges the relevance of joint ventures and strategic alliances as ways of internationalizing (Johanson and Vahlne 2009).

This article intends to retrieve and explore one of those alliances forged in Europe, which had the incentive to deviate from the practices of the majority because it was a company with exclusively European partners. The article does this from the perspective of a peripheral country (Spain) in the global economy and from the special status of at least one of the partners in a monopoly. Finally, it follows case study methodology, which aims to delve into the complexity of the processes and the phenomena at hand. ${ }^{1}$

The article responds to the need for an alternative approach to industry analysis that is particularly important for technology-based industries and the most turbulent high-tech industries; an approach focusing on complicated networks of relations and taking into account multiple possible configurations of value creation and delivery, not merely the typical supplier-customer scenario (Klincewicz 2005).

In terms of its structure, after the introduction the first section examines the creation of European Silicon Structures as a strategic alliance in the European semiconductor industry. Sections two and three look at the case of Spain and the role of demand using the example of Telefonica. Conclusions are presented in the final section.

\footnotetext{
${ }^{1}$ In Yin's (Yin 1993, 59) definition, a case study is an empirical inquiry into 'a contemporary phenomenon within its real-life context and addresses a situation in which the boundaries between phenomenon and context are not clearly evident.'
} 


\section{A strategic alliance in the European semiconductor industry: European Silicon Structures}

The case study (European Silicon Structures-ES2) emerged as an initiative formed under the umbrella of supranational institutions in order to promote the unification and harmonization of the market. In the 1980s, the European Community prepared the end of its internal trade barriers for the beginning the next decade. The region shifted in telematics from the national champions to cooperation strategy, possibly because several states simultaneously faced issues of scale. On the other hand, the stock traded by young companies, which was almost inexistent some years before, was booming. ${ }^{2}$

One important feature in Europe was the lack of an indigenous electronics industry (bait for the semiconductor industry and driver, in turn, of electronics in general) and an absence of management culture; circumstances that were compounded by a lack of correspondence between the tremendous emphasis on science and technology and production and marketing. Politicians and European business elites looked to lasting technological innovation and risktaking in a favourable socio-economic climate as the best hopes to survive in the global competition (Forester 1989, 289). ${ }^{3}$

The dominance of the semiconductor market by standardized products or commodity chips allowed some differentiation in speed chips and in quality control, which was a peculiarity of the Japanese. Rising R\&D costs and climbing capital investments forced the firms to increase their sales to recover these costs. Despite the very low and falling marginal costs of chips and

\footnotetext{
2 (Sandholtz 1992, 20; Fortune, April 27, 1987). Some pioneering analysts stressed European (and French) backwardness (Pouderoux 1968, 22).

3 The Roundtable of European Industrialists think tank considered it crucial to abolish national standards opposed to free trade in the EC and the remaining telecommunications monopolies, as well as to remove all obstacles to cross-border mergers and acquisitions and to extend EC research programmes beyond the precompetitive stage (Dataquest 1991, 104).
} 
recurrent competitive gluts in this highly cyclical industry, the omnipresence of chips in ICT compelled the large companies towards_vertical integration for more powerful chips. Three relevant processes occurred here. To begin with, the restructuring of research-oriented connections in the case of Philips and Siemens and the merger between the Italian SGS with the semiconductor operations of the French Thomson. Another process was the increasing quest for government subsidies and protection and the third involved sidestepping the commodity market through the formation of a new company (Faulhaber and Tamburini 2012)

The plans for a new European venture in the semiconductor industry were based on several assumptions about, for example, market trends and nature. In the context of a very fastgrowing full-custom CMOS circuits market, it was expected that this might more than triple in the period 1985-1988 in Europe, reaching \$1.44 billion in 1991. An increase in full-custom circuits from $\$ 120$ million in 1984 to $\$ 1$ billion in 1991 was possible. The new firm would try to cover no less than one-fifth of the 50 per cent for prototypes and small volume series, a market amounting to \$110 million in 1991.

European customers needed professional, industrial, and specialized data-processing electronics based on circuit series preferably with reduced design and manufacturing times in order to shorten the production process. Meeting this specific need was a significant differentiation in comparison to US and Japanese companies, which were more geared towards large series. Expertise in high-tech silicon compilers would give speed of design; 
speed of prototype and small-series manufacturing would be achieved through innovative technology. 4

At the time, Europe provided around 10 per cent of the world output of semiconductors. Several EEC efforts were engaged in increasing that share, including the peaceful Mitterrandist EUREKA project. It was one of several programmes with a high degree of risk, involving cross-country cooperation on a massive scale between firms in the early stages of the process leading from research to industrial application. ${ }^{5}$

Seven participants of the first EUREKA programme of 1985 helped establish a pan-European start-up under French initiative named European Silicon Structures, or ES2. Its objective was the production of prototypes or small batches (less than 50,000 units) of full-custom circuits. The new firm would train the designers of client companies, assist them in their work, provide design tools, and finally offer a packaging and testing service (Forester 1989; Mytelka 1990; Sandholtz 1992). This new undertaking was possible thanks to the sum of an original idea coupled with the transfer of the managerial and technical knowledge accumulated by the founding trio in several European and US firms from the sector, as well as financial backing and state political support. The actual brain behind ES2 was the French engineer and well-

\footnotetext{
${ }^{4} 80$ per cent of all European equipment was manufactured in series with less than 5,000 parts; the plant would be equipped with an electronic masker: PRS Report Science \& Technology, November 8, 1985, 40.

${ }^{5}$ French president Francois Mitterrand learned about the Silicon Valley organization in situ, made it a source of inspiration for a European common technology, and met with leaders in computer chips and information systems: Le Monde, December 28, 1985; The New York Times, March 26, 1984. Advisers to Mitterrand included Hubert Curien, former president of CNES (France's national space agency), who conceived EUREKA to counterbalance Reagan's plan for a Strategic Defense Initiative (SDI) - a space-based missile defence: (Friend 1998, 228; Business Week, 3.108-3.121, 1989, 158). The ES2 project was estimated at ECU 94 million; other projects include: the Philips-Siemens MEGA (the base of the controversial JESSI (Joint European Semiconductor Initiative)) at a total cost of some ECU 2,000 million; the EUROCIM project, whose cost was around ECU 30 million; and the EUROLASER project, costing around ECU 80 million (Cowhey and Aronson 1993, 157; European Commission, Press Releases, 31/10/1986, 2).
} 
trained cosmopolitan manager Jean-Luc Grand-Clement, who contacted business elite member Robert R. Heikes, head of the National Semiconductor Corporation's operations in Europe and Latin America. ${ }^{6}$ They consecutively brought in Robert W. Wilmot, chairman of the British computer maker ICL Ltd., and a London-based venture capital firm, Advent, the overseas branch of Boston's TA Associates, America's largest group in its class. ${ }^{7}$ Some of them were participants in previous projects. Heikes and Grand-Clement, director general and general manager at Motorola Europe and Glasgow, respectively, were also involved in a plant project for semiconductors in Malta. ${ }^{8}$

Because a large amount of capital (\$50 million) was needed to build the company and to equip the plant and research labs, the founders decided on a pan-European firm, more intricate than the previous simple bilateral ventures. ${ }^{9}$ Advent injected the first half a million dollars in

\footnotetext{
${ }^{6}$ Engineer of the École Nationale Supérieure de Télécommunications, experienced in Eurotechnique and in Electronics in CIT-Alcatel, as well as a founder of the L'Occitane of electronics (Le Monde, September 4, 1985).

${ }^{7}$ Motorola taught Grand-Clement 'the importance of having solid financing and a clear strategy from the start'. When Grand-Clement, former senior manager in Motorola Europe, contacted Saxby, Saxby's secretary said: 'There's a Frenchman on the phone, and he sounds a bit like Inspector Clouseau'(Saxby 2012). Some sources added other venture capital to Advent: Technoventures and Euroventures, founded in 1984 by the European group Asea/Fiat/3M/Olivetti/Bosch/Volvo (Lipnack and Stamps 1993, 124) and it was backed by a number of giants including Pirelli and Saint-Gobain (Fortune, April 27, 1987), Four Seasons/Alfa-Laval, the Fjarde AP Fund, SFP, and others such as Schroder Ventures (Investors Chronicle, 86, 1988, 81; PRS Report Science \& Technology, November 8 1985, 9; Les Echos, 5/4/1995). Advent appears sometimes as coordinator of funding and Robb Wilmot as the prime mover in ES2 (Investors Chronicle, 75, 1986, 61). Wilmot came from a 16-year stay at Texas Instruments Inc. and from the post of executive chairman of International Computers Limited (ICL) (1984), ultimately becoming managing director of its British subsidiary (PRS Report Science \& Technology, November 8, 1985, 40; The New York Times, October 24, 1990). Wilmot commented in 1987: 'The day may not be far ahead when it will cost less to design a custom chip than buy a secondhand car': Semiconductor International, 12(1-6), 1987, 76.

${ }^{8}$ Heikes explained that the advantages of Malta were a comparatively low wage scale combined with common market preferences; negotiations continued in 1974: Industrialization: Motorola Semiconductors, October 1, 1973, Wikeleaks, 1973VALLET01930_b; April 10, 1974, 1974VALLET00677_b.

${ }^{9}$ French-Italian export oriented agreement Sescosem-Mistral (Pouderoux 1968, 22). Rod Attwooll confessed that the involvement of some depended on the involvement of others: 'they all separately said they would invest if $X$ would - and promised to talk to X. While weeks and months passed. In the end, we got them all into a room in a
} 
seed capital and offered its offices in the early days, and ES2 eventually raised near to $\$ 100$ million in corporate investment, venture capital, and grants (Campbell 2003). ${ }^{10}$ The situation in 1985 was as follows: the two leading European venture capital companies, Advent (London and Belgium) and Techno-Venture Management (Munich), as well as Alpha Associates in France, Orange Nassau in Holland, and Four Seasons in Sweden, had provided \$4 million. Industrial investors and financial institutions from six European countries would provide the remaining \$61 million, in equal amounts, with the absence of any non-European sources. The capital structure should have been, in principle, as follows: 25 per cent from the founders and the personnel; 15 per cent from venture capital; 30 per cent from large manufacturers; and 30 per cent from 'institutions'. ${ }^{11}$ Table 1 displays subsequent financial operations for several years.

hotel in Brussels and told them to get down to talking to each other. With hindsight, silicon fabrication on venture capital money was a tall order' (Campbell 2003, 59).

${ }^{10}$ A source reported the ambitious programme: $\$ 65$ million to start, or $\$ 100$ million over 5 years for a full setup: PRS Report Science \& Technology, November 8, 1985, 40. Sources differed on data: \$46 million according to Fortune, April 27, 1987; Advent seeded ES2 with about $\$ 5$ million and there was start-up capital of $\$ 60 \mathrm{~m}$ according to The Economist, 303, 1987, 71; \$60 million was gathered from eight European corporations (including Italy's Olivetti, Sweden's Saab, the UK's British Aerospace, and the Netherlands' Philips) according to The Scientist, November 28, 1988. Venture Capital disbursements grew by a factor of 6.4 from 1978-1986. Capitalization of ES2 in 1988 was at 44 million dollars, similar to Matra Harris and Mietec. ES2 had the most substantial venture-capital backing seen so far outside the US: Electronics, 59, 1986. Some scholars considered the company as 'an ambitious - some might say foolish - stab at creating the first European-based designer and developer of integrated circuits at a time when a worldwide glut of silicon chips was wreaking havoc with the industry' (Brooke and Penrice 2009, 66).

${ }^{11}$ The Four Seasons intended to present the project to a number of investment groups in Sweden, including Folksam and Aktiv: PRS Report Science \& Technology, November 8, 1985, 36. The project did not include dynamic countries like Ireland, then on the way to becoming a European Silicon Valley, as asserted by the government: Public Papers of the Presidents of the United States (Reagan, Ronald 1986, 801). 
Table 1. European Silicon Structures, financing

\begin{tabular}{c|lc}
\hline \multicolumn{2}{c}{ Date } & \multicolumn{1}{c}{$\begin{array}{c}\text { Financing } \\
\text { (\$Million) }\end{array}$} \\
\hline \multirow{4}{*}{ Dec. 1985} & Advent, London; Techno-Venture Mgmt. Corp. & 5 \\
\hline & Brown Boveri and CIE of Switzerland; & 25 \\
\cline { 2 - 3 } & Ing. C. Olivetti \& Co. (Italy); N. V. & \\
\cline { 2 - 3 } & Philips (Netherlands); Saab-Scandia & 5 \\
\cline { 2 - 3 } & AB (Sweden) & 9 \\
\hline \multirow{4}{*}{ Jan. 1986 } & British Aerospace & \\
\cline { 2 - 3 } & Banque International in Luxembourg; & \\
\cline { 2 - 3 } & European Investment Bank & \\
\hline
\end{tabular}

Source: Compiled by author using data from Dataquest, June 1988, 205.

ES2's structure was established during the most awful recession in the semiconductor industry’s history (Cowhey and Aronson 1993). ${ }^{12}$ As a main feature, ES2 had complex legal development, which allowed it introduce itself as a local company in the various countries in which it was implemented (PRS Report Science \& Technology, Europe \& Latin America, January 26, 1988, 11-12). ${ }^{13}$ National boundaries were still an issue, requiring export licenses even within Western Europe as well as the usual transport documentation. Lacking the European legal status for a pan-European company, ES2 was incorporated in Luxembourg as a parent company of several subsidiaries in each country in which it was implemented; a holding company with national subsidiaries. ${ }^{14}$ The composition of the board of directors displayed in Annex 1 shows the presence of founders, financers, and some executives from the sector, including the French-international Bernard Pruniaux, formed in France, trained in

\footnotetext{
${ }^{12}$ See also The New York Times, August 1, 1988.

${ }^{13}$ In Germany it was established as ES2 GmbH (Wedgwood ed. 2013, 146); in the United Kingdom as ES2 Limited, and in the Netherlands as ES2 Netherlands B.V. The designs of chips with ES2 software were translated by their computers into etching instructions for the $\$ 4$-million Able 150 electron-beam machines, manufactured by the Perkin-Elmer Corporation. It was also considered as a 'Chip Maker Without a Country', The New York Times, August 1, 1988; while others considered it geocentric oriented (Vasudeva 2006, 48). More accurately, it was called a 'company with many countries' (The Scientist, November 28, 1988).

${ }^{14}$ The Scientist, November 28, 1988.
} 
the USA, and acting in France. The situation changed in 1994 with the arrival of new names. ${ }^{15}$

ES2 presented a decentralized structure since its production, assembly, and testing plant was located at the Rousset Technology Centre, near Aix-en-Provence, and one of the technologyintensive departments (software design) was located in the United Kingdom. ${ }^{16}$ In this sense, its birth coincided with the first phase of the microelectronics 'technopole' in the town of Rousset, characterized by the emergence of a microelectronics cluster in the Bouches-duRhône region when the government aimed to enter the microelectronics industry via public enterprises and joint ventures with North American technological partners. ${ }^{17}$

\footnotetext{
${ }^{15}$ Pruniaux: an engineer in electronics (Toulouse), with two years at Leti (Grenoble CENG), and 4 years at Bell Labs (New Jersey), which allowed him to acquire considerable technical expertise in semiconductors. At the French facility of Texas Instrument (Nice), he was one of the pioneers of the reduction of the dimensions of the chips to increase their performance and reduce their cost. As an industrial director at Eurotechnique, a St. Gobain-National Semiconductors joint venture (1979), he contributed early on to the launch of the microelectronics cluster in Rousset. He retired in 2008 at Atmel: Letter to Steve Laub, president and chief executive officer at Atmel Corporation: EX-10.10 2 f51611exv10w10.htm EXHIBIT 10.10, October 17, 2008. Jean Pierre Demange was vice president and director of ES2 for Southern Europe; the general manager was Manfred Koslar, developer of the signal computer. The situation in 1994 was as follows: managing directors W. Koepf and Bernard Pruniaux; research director and technical director Eric Detoullin; product managers Eric Detoullin and Lucien Brau; purchasing manager Jean Louis Palazzo; marketing manager and advertising/publicity manager Christian Fleutelot (graduated from the École centrale de Lyon with a post-graduate degree in micro-electronics; quality engineer at MATRA defence from 1986-1988); sales manager Jean Yves Lesaux (Wedgwood ed. 2013, 36). Two examples of the mobility of technicians in the big companies: Lucien Brau (Eurotechnique and Texas Instrument), director of back-end operations at European Silicon Structures; Christian Dupuy (Motorola) developed product engineering capabilities and analogue design capabilities at European Silicon Structures.
}

16 (European Communities Commission 1989, 48, 207); (Telefónica, Memoria 1985, 6). A decentralized structure of design centres was planned: first in Paris, Munich, and London, then, in 1986, in Milan, Stockholm, and Edinburgh (PRS Report Science \& Technology, November 8 1985, 36). Three production plants were planned in the UK, France, and Germany (Le Monde, September 4, 1985). It is worth noting the poetic vein of the French grand press: 'Si drapeau elle a, il est bleu avec un cercle de douze étoiles d'or, l'emblème de la CEE' (Le Monde, March 28, 1987).

17 Training was possible at the university centre close to the factory (Meister 2001, 159). For most people Rousset was the capital of a Provençal Silicon Valley with 25 per cent of French microelectronics located there. The US Milken Institute identified eight key ingredients in the creation of high-tech clusters to grant them success from the start. Firstly, the presence of cutting-edge civil and military research centres and institutions, which, combined with a network of entrepreneurs and venture capitalists as the second noteworthy element, 
The entry into operation was a gradual process. As for many companies in the semiconductor industry, ES2 was at the beginning a 'fabless' firm, or a firm without a plant, geared towards technological breakthroughs in microchip design, but subcontracting its products before manufacturing began. The Rousset production plant, inaugurated in 1987, began to assemble and test circuits, with silicon wafer processing still being performed at Exel Microelectronics in California through a subcontracting formula. ${ }^{18}$ As a horizontal alliance, ES2 tried quickly to reach economies of scale and critical mass to carve a profitable niche of small production series in the region's $\$ 5$ billion semiconductors market. Leading-edge e-beam technology (direct-write process designs onto silicon wafers with an electron-beam machine) was chosen and enabled it to drastically cut (by more than a half) the delivery time for prototype chips and the prices of its competitors, namely North American and Japanese firms (Saxby 2012; Campbell 2003). ${ }^{19}$ Surprisingly, among future clients, ES2 missed the two most dominant and in some ways opposing electronics companies in Europe: Thomson and Siemens. ${ }^{20}$

translate into the rapid adoption of technology. The remaining six components are: a skilled and educated work force; technology spillovers from nearby high-tech industries; the availability of venture capital; high quality of place; and two favourable elements related to low costs - cost of living and cost of doing business, including low land prices: Strategy+business, July 1, 2001.

18 In February 1986, Exar Integrated Circuits, a publicly owned Californian company, acquired Exel Microelectronics for $\$ 5.5$ million. Exel operated as a subsidiary of Exar and maintained an independent plant and R\&D staff (Dataquest 1988, 209).

19 PRS Report Science \& Technology, Europe \& Latin America, January 26, 1988, 11-12; Business International, 33, 1986, 241. VLSI Technology Inc., a Californian firm worth \$125 million and founded in 1979, specialising in complex high-performance ASICs and ASSPs, was one of ES2's main competitors. ES2 was an early buyer of the Aeble 150 machine since it bought the third machine manufactured by Perkin Elmer and installed it first at Exel in October 1986, taking on ASIC designs from April 1987, 1-338. The VLSI subsidiary, Compass Design Automation, Inc., supplied software and design libraries to the broad commercial ASIC and electronic design automation marketplaces. Grand-Clement considered that the gate array market was dominated by 'old-fashioned methodology and a clumsy, rough-and-ready approach' (Profiles: A Worldwide Survey of IC Manufacturers and Suppliers, 1998, 2-446; Electronic Engineering 60, 1988, 23).

${ }^{20}$ Siemens, engaged in the Mega project with 1Mbit technology from the Toshiba family, showed signs of demoting the French-Italian firm SGS-Thomson, resulting in the irritation of SGS-Thomson and the French 
Thomson and SGS stressed that their moves to attack this sector resulted from their own market analyses and were under consideration well before the creation of ES2 was announced. Thomson, moving to attack this sector on the basis of its own analyses, offered Siemens to lock the market with a joint venture to manufacture circuits on request. After the Germans' refusal, Thomson sought to enter the market with the technical support of the English and the Americans (Bonno 1986).

The business plan failed because the e-beam lithographic machine had a tenth of the throughput anticipated for the specifications and the advantages on prices were not met. In reality, the technically feasible and differentiating plan placed ES2 outside conventional chip manufacturing and inside a shared niche between FPGAs and the semi-custom and fullcustom markets of several firms. ${ }^{21}$ As Saxby recognized, at the time ES2's members raised a 'truckload of money very successfully, had a fantastic idea, failed at engineering implementation, then ran out of money... and were bought by ATMEL', a Californian firm looking for a European manufacturing base converted into a worldwide leader in the design, manufacturing, and marketing of advanced semiconductors. ${ }^{22}$

government. SGS-Thomson vindicated its leadership in erasable programmable read-only memory-chip (EPROM) technology and equal financial participation from all three firms (Sandholtz 1992, 293).

${ }^{21}$ LSI Logic Corp., VLSI Technology Inc., and Taiwan Semiconductor Manufacturing Co. Ltd.: EE Times Europe, January 9, 2014. In 1991, leading European suppliers often concentrating on niche markets and application-specific ICs included, together with ES2: ABB-Hafo (Sweden); Austria Microsysteme (Austria); GEC Plessey Semiconductors (UK); Matra-Harris Semiconducteurs (France); Mietec (Belgium); and Telefunken (Germany). Non-European companies included, among others: AMD (USA); Analog Devices (USA); Fujitsu (Japan); Matsushita (Japan); and Mitsubishi (Japan) (Fletcher 2013, 168). Some scholars present ES2 as an illustration of how co-investment by semiconductor-using companies can facilitate access to key components while spreading the cost (Collins and Doorley 1994, 310).

22 (Campbell 2003, 59; Saxby 2012; Le Monde, September 10, 1995; "Atmel and Virage Logic Grow Partnership for 0.13-micron SoC Designs", PR Newswire, January 21, 2003). In Saxby's words 'the vision of ES2 couldn't happen really. And really they needed a change of business strategy which was forget the e-beam machine and become more conventional.' Advanced Technology-Memory \& Logic (ATMEL), founded by two members of the Perlegos family and T.C. Private Funds, specialized in the design, manufacture, and marketing of high-speed 
Because of the narrowness of the European market, ES2 paid a price to overcome the worst aspects of fragmentation and the high costs of coordination in the collaborative venture (Guile 1987).

Possibly, the main reason for the let-down was in the conception, which was a sort of trap: a niche firm had advantages for expansion but also difficulties because of the strict limits of the market. ES2's share in the European semiconductor market in 1989 was 0.2 with $\$ 17$ million in sales. The pan-European company ranked in the markets of different products as follows: $116^{\text {th }}$ in 1989 among European companies in the semiconductor market with $\$ 18$ million; $35^{\text {th }}$ in the European digital MOS IC; $33^{\text {rd }}$ in the European CMOS IC; $21^{\text {st }}$ in the European MOS logic; $19^{\text {th }}$ in the MOS ASIC; and $42^{\text {nd }}$ in the European integrated circuit. With 17 million dollars in revenues for ASIC in 1989, ES2 had 1.44 per cent of the total European revenues in the ASIC market (Dataquest 1990). ${ }^{23}$

ES2 rearranged its organizational structure, came out of the European market, and worked to insert itself into wider networks. Backed by some US venture capital, it set up United Silicon Structures, or US2, an unsuccessful North American subsidiary, which drowned due to financial and management problems. ${ }^{24}$ In October 1987, ES2 purchased a software and design firm in Japan called Best to convert it into a sales agency for ES2's products in Japan. Beyond these plans, ES2 wanted to form a new production firm under the name of JS2, or Japan Silicon Structures. ${ }^{25}$ ES2 and Development Co. formed a joint venture, European CAD

and analogue products (Dataquest June 1988, 113). ES2 sold off the CAD division to Cadence where O'Donnell helped integrate it.

${ }^{23}$ Dataquest, European Semiconductor Market Share Estimates Final 1989, 1990; A European Semiconductor Industry Service Report (Dataquest 1991, 6).

${ }^{24}$ Robin Saxby was in charge of making US2 profitable; Tim O’Donnell also joined US2 (Saxby 2012).

${ }^{25}$ Dataquest, June 1988, 207; Business Week, 3.094-3.097, 1989, 102. 
Developments Ltd., specialized in research and development activities within the EDA and ASIC design markets. ${ }^{26}$ Later on, they planned to expand by linking with the United States and a leading venture from West Germany, a country that was absent as co-owner.

ES2's path was remarkably linked to that of Lattice Logic, a spin-off company and owner of an original automatic Computer Aided Design (CAD) system to layout integrated circuits in the gate array style. First, since 1985, ES2 had been a customer of the pioneering silicon compiler from Lattice Logic, as was the case for several key enterprises, including Ferranti Ltd. The company's Solo 1000 was based on Lattice Logic's Chipsmith system, enabling designers to produce full-custom and optimized designs. ${ }^{27}$

Secondly, ES2 strengthened its managerial and technical capacity with the arrival of John Gray and Irene Buchanan to the software division, with Gray serving as VP of design technology. ${ }^{28}$ Thirdly, ES2 bought its former provider Lattice Logic in 1987 (Dodgson1989; Dataquest 1991).

ES2 formed agreements with several European, Japanese, and North American companies, as displayed in Table 2 .

\footnotetext{
${ }^{26}$ Moody's OTC Industrial News Reports, 20, 1989, 1870; Dataquest 1991, 105. European Cad Developments was registered on January 8, 1990 in London and later dissolved.

${ }^{27}$ Meanwhile, Solo 2000 was based on the SDA Systems family of integrated CAD tools and incorporated compiled macro blocks (Dataquest June 1988, 205). ES2 signed contracts for SOLO 1000 and SOLO 1200 software and Qudos QUICKCHIP PLUS software and arrangements for the supply to academic institutions were in hand: Journal of Semicustom ICs, 7-8, 1989， 45. European Silicon Structures used CAD SUN 3/SOLO 1400 for the design, analysis, and simulation of an FSK technology 1.2u filter. ES2 provided goods for educational activities in Essex through the London University Consortium (Jones and Buckley 1989, 16).

${ }^{28}$ Lattice Logic was set up by two PhD graduates of John Gray's, a lecturer in computer science, when in 1980 he left the University of Edinburgh. It was hailed as one of the most exciting indigenous start-ups from Silicon Glen (Business Herald, April 28 1986, 15). Irene Buchanan, John Gray, and Tom Kean founded Algotronix in 1989, pioneering the use of FPGA chips. Japanese connection: Lattice licensed its 64 KSRAM design and technology to Seiko Epson/S-MOS (Dataquest, October 1986, 28).
} 
In 1989, ES2 had revenues of $\$ 19.3$ million (45 per cent higher than in the previous year but substantially below the hope its founders had of $\$ 100$ million in five years) and ranked number one among the participants in pan-European technology programmes (US Congress $1991) .^{29}$

Table 2. Global European Silicon Structures agreements with companies

\begin{tabular}{|c|c|c|}
\hline Partner & Year & Purpose \\
\hline Etec Systems* & & $\begin{array}{l}\text { Development of technology for direct-write gate array } \\
\text { personalization }\end{array}$ \\
\hline \multicolumn{3}{|l|}{ Jenoptika } \\
\hline Compass Design Automation & & $\begin{array}{l}\text { Compass would provide its customers with access to } \\
\text { Advanced Risk Machines }\end{array}$ \\
\hline Siemens & & $\begin{array}{l}\text { Allowed ES2 to produce chips with the Siemens } 0.5 \text { - } \\
\text { micron CMOS process }\end{array}$ \\
\hline Phoenix VSLI & & $\begin{array}{l}\text { United Silicon Structures would make the prototypes } \\
\text { and VLSI would handle the volumes }\end{array}$ \\
\hline Cascade Design Automation & & $\begin{array}{l}\text { Provide } 0.7 \text {-micron process technology using } \\
\text { Cascade's design tools and ES2's process technology }\end{array}$ \\
\hline \multicolumn{3}{|l|}{ Mitsui\&Co. Ltd } \\
\hline Lattice Logic & 1985 & Export Lattice's compiler to Europe \\
\hline $\begin{array}{l}\text { Solomon Design } \\
\text { Associates (SDA) Systems }\end{array}$ & 1986 & $\begin{array}{l}\text { Market SDA Systems' design family in Europe and use } \\
\text { it in several design centres }\end{array}$ \\
\hline Philips-Elcoma-Texas Instruments & 1986 & Cooperate on the System Cell standard cell library \\
\hline Philips-Texas Instruments & 1987 & $\begin{array}{l}\text { Manufacturing of the System Cell: TI and Philips } \\
\text { would supply volume parts and ES } 2 \text { would provide } \\
\text { prototypes and low-volume quantities }\end{array}$ \\
\hline Exel & 1986 & Subcontract production to the Exel plant \\
\hline Development Co. & 1990 & R\&D within the EDA and ASIC design markets \\
\hline Sun Microsystems & 1987 & $\begin{array}{l}\text { Amalgamate the ES2 Solo } 2000 \text { v.i.s.i. design system } \\
\text { with the Sun-3 workstation }\end{array}$ \\
\hline
\end{tabular}

Source: Compiled by author, * The agreement with Etec Systems was named Eubeam and the agreement with Development Co. was called European CAD Developments Ltd.

29 The strategic Joint European Semiconductor Initiative (JESSI), an initiative to restore European competitiveness in microelectronics, was one of the most ambitious collaborative projects launched under EUREKA together with the German-dominated High Definition Television (Kassim and Menon, eds. 2002, 233; Marchipont 1997, 115), considered the upstream cousin of JESSI, both involving chips (Leuenberger and Weinstein, eds. 2012, 28). The European research programmes tried to provide central coordination for European national companies and a platform to take a more pro-active approach towards developing standards for Europe and worldwide (Dataquest's eighth annual European Semiconductor Industry Conference, Munich, $1989,8)$. 
In 1989, ES2 had revenues of $\$ 19.3$ million (45 per cent higher than in the previous year but substantially below the hope its founders had of $\$ 100$ million in five years) and ranked number one among the participants in pan-European technology programmes (US Congress $1991)^{30}$

ES2 was a player in the general ESPRIT and specific JESSI projects, beginning with the IDPS, coordinated by Philips International to provide the European IT industry with the basis of a full service for designing and producing systems integrated on silicon in various different foundries. The rest of the participants were Bull SA., France; GEC Marconi Electronic Devices Ltd., United Kingdom; and Robert Bosch GMBH, Germany (CORDIS, Publications Office of the European Union). Another two projects were 5075 IDPS Integrated Design and Production System with Philips International, Robert Bosch, SGS-Thomson Microelectronics, Siemens, Plessey, STC-ICL, and Bull, and the 5080 JPL Joint Logic Project with Philips International, Plessey, Siemens-Nixdorf, Telefunken Electronic, SGS-Thomson Microelectronics, Mietec, and Matra-MHS (ESPRIT, 1991).

European Silicon Structures entered into the Technology Initiative in BiCMOS for Applications (TIBIA), coordinated by Nederlandse Philips Bedrijven Bv, which aimed to satisfy the components needs of the electron ic equipment industry for bipolar and BiCMOS ICs technologies at the $0.7-0.5$ micron generation, together with the design and CAD expertise to exploit the technology. It enjoyed the participation of 17 scientific institutions and

\footnotetext{
30 The strategic Joint European Semiconductor Initiative (JESSI), an initiative to restore European competitiveness in microelectronics, was one of the most ambitious collaborative projects launched under EUREKA together with the German-dominated High Definition Television (Kassim and Menon, eds. 2002, 233; Marchipont 1997, 115), considered the upstream cousin of JESSI, both involving chips (Leuenberger and Weinstein, eds. 2012, 28). The European research programmes tried to provide central coordination for European national companies and a platform to take a more pro-active approach towards developing standards for Europe and worldwide (Dataquest's eighth annual European Semiconductor Industry Conference, Munich, $1989,8)$.
} 
10 manufacturing companies (Annex 2), including some Spanish firms and centres. ${ }^{31}$ Critical voices acknowledged that the increase in trans-European collaboration funded by the EC was a major success of the programme, but also made it sensitive to funding reduction (US Congress, 1991).

\section{Spain}

Spain occupied modest positions in Western Europe as a producer in the semiconductor industry ( 5.5 per cent of the total, far from Germany and the United Kingdom (UK)), and as a consumer, with 6 per cent. This Mediterranean nation lagged behind core Western countries but was the major semiconductor market of a group of regional category, including Southern and Central countries (Switzerland, Austria, Portugal, Greece, Turkey, and Malta). Several major telecommunications, data processing, and consumer electronics manufacturers have located plants in Spain, attracted by low wages and cheap land (Dataquest 1990).

Graph 1. Total European semiconductor market, 1990 (\$M)

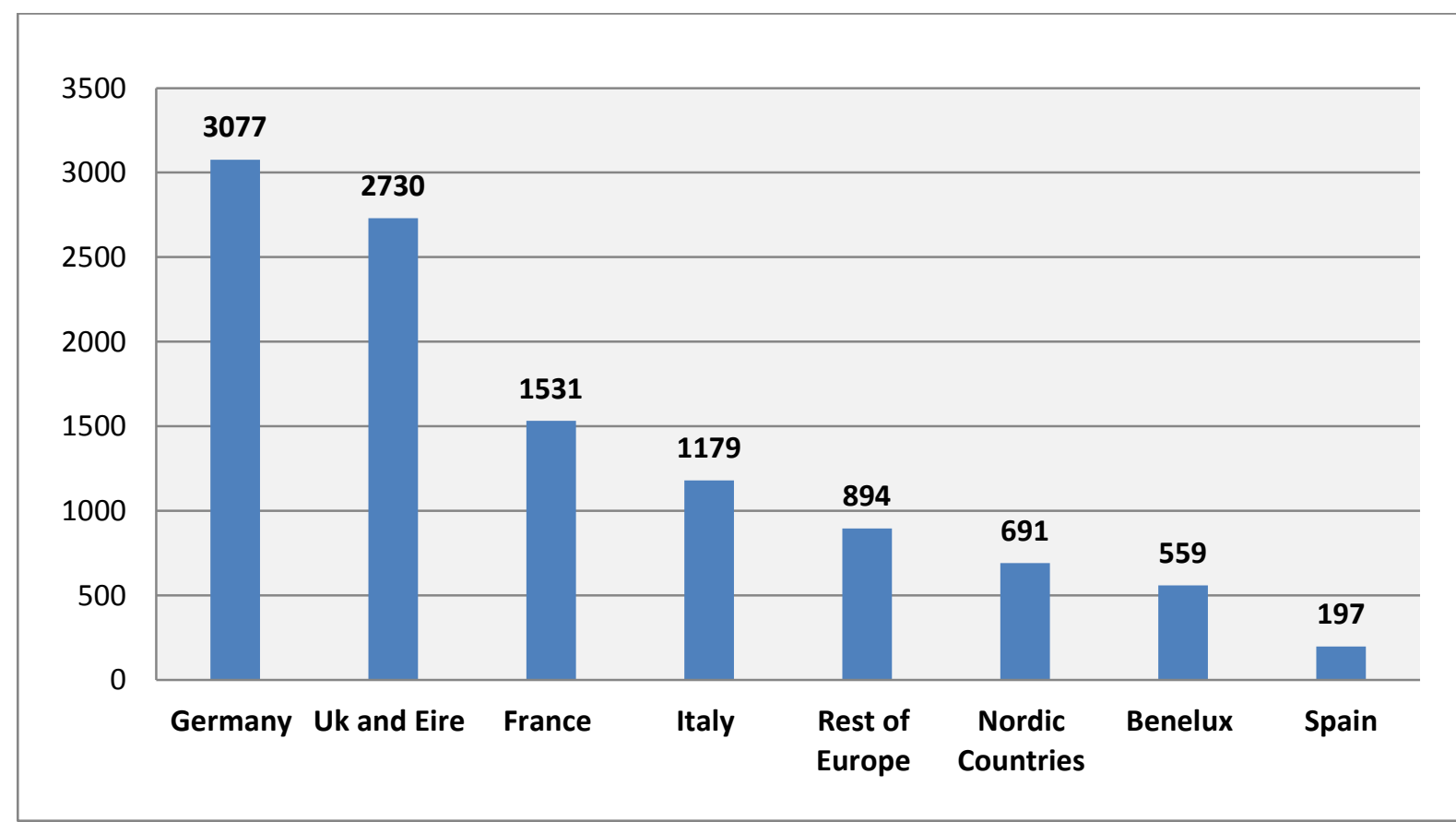

${ }^{31}$ CORDIS June 21, 1994. 
In Spain, the first initiatives in microelectronics succumbed to uncertainty and the ineptitude of the government in the first phase of the democratic transition after a long period of Francoist dictatorship, as happened with the technical mission to Silicon Valley, heart of high technology, which encouraged the North American AMI to make a plan to settle on Spanish soil and which also failed. The project to manufacture chips with Motorola as a technology partner also suffered a similar fate. The CTNE (Compañía Telefónica Nacional de España) tried to assimilate know-how by sending technicians to Motorola's design centre in Switzerland, but despite advances and good rapport, the multinational declined offers because of the unattractiveness of the Spanish market, according to the company's impression. In comparative terms, American Micro Systems prompted a similar project in Austria and one of the negotiators of Motorola, Pistorio, created the Società Generale Semiconduttori (SGS) in Italy, an innovative joint venture between Olivetti and TELETTRA (Calvo 2014). It teamed up with ATT in bipolar circuit technologies and merged with Thomson in 1987, setting up one of the two major blocks in the European silicon industry, alongside the Central European axis Philips-Siemens. This was in sharp contrast with Italy, which was dedicated to the culture of the national champion in a context of world market predominance. ${ }^{32}$ A pre-agreement with the American Silicon Valley Supertex did not flourish either. This firm had been very interested in the infrastructure of the National Centre of Microelectronics to manufacture

\footnotetext{
${ }^{32}$ Juan Mulet Melià, conversation with the author, Barcelona, 16/5/2013. The multinational Motorola had five design centres in Europe: East Kilbride (Scotland), Geneva (Switzerland), Munich (Germany), Toulouse and Bordeaux (France). Motorola (fourth in the whole semiconductor industry in terms of revenue after NEC, Toshiba, and Intel and, in 2003, $19^{\text {th }}$ among multinational companies in terms of volume of investment in R\&D) was a pioneer in the introduction of the first 32-bit microprocessor (MC68020), containing 200,000 transistors (Fletcher 2013, 129). Its semiconductors section accounted for approximately 30 per cent of its sales; one-third of their total revenues was generated outside the US and 7.6-8.3 per cent of its revenues was allocated to R\&D (Dataquest 1989, 215). Shortly before the end of the decade of 1980, the CTNE leaned on AMPER to create the joint mobile venture Telcel Motorola (Calvo 2014, 242; Forsgren 2013, 19; Oral History of Pasquale Pistorio Interviewed by Doug Fairbairn, 26/4/2010; 'Interview with Pasquale Pistorio', EE Times, 25/3/2005).
} 
high-voltage chips for consumer goods in Spain. According to Solana, in order to favour the balanced location of cutting-edge technologies for factories throughout the Spanish territory, Barcelona was one of the sites considered to compensate for ATT and Fujitsu projects in Madrid and Malaga. ${ }^{33}$ Without a doubt, the public sector, represented by the government and the INI, appeared in the first plans to create a joint venture with ATT but this road was closed. $^{34}$

Spain was the scene of several international alliances in the microelectronics industry sponsored by the government, public institutions, and companies. California Micro Devices (CMD), manufacturer of high-performance electronic components through its Thin Film, ASIC, and Microcircuits Divisions, agreed with Telefonica to form a subsidiary named California Micro Devices, Spain. CMD would provide technology and training and about \$2 million in investment for around one-third of the ownership and would market its components to military and civil, aerospace, medical, computer, and communications customers. Products sold in Spain would serve Spanish defence needs. ${ }^{35}$

\footnotetext{
${ }^{33}$ Minutes of the Board of Directors of Telefónica (MBDoT) 28/10/1987; Telefonica compared the project with a company, no doubt Supertex, advanced in the 'smart power chip' (several technologies integrated on a single chip), with that of ATT: Popular Science, November 1985, 85; El País, 15/10/1987. In 1986, IBM embarked on a decentralization process in successive steps: transfer of authority to the national subsidiaries; separating these into two groups according to a scheme of magnitude and speed of market growth (France, Italy, and Germany/rest of Europe), linked to the central offices in Paris (Thakur et al. 1997, 304). IBM opened an international Software Development Centre in Barcelona (MBDoT, 28/10/1987; Smidt and Wever 2012, 39. Telefónica backed the Everest project to develop tools for testing chips with $\$ 40$ million dollars: Minutes of the Steering Committee of Telefónica (MSCoT), 30/1/1991.

${ }^{34}$ Agreement between ATT-Compañía Telefónica Nacional de España, 26/7/1984, INI Historical Archive.

${ }^{35}$ CMD (1980) joined with Capsco Sales (1976), a thin-film company, and in 1982 it established Custom MOS Arrays (CMA), which designed, manufactured, and marketed HCMOS cell-based ICs and gate arrays in the 200to 2,000-gate range before merging in 1986 with CMA into one new firm. Components: thin-film passive components for hybrid assemblies/gate arrays/cell-based ICs/and non-impact print head substrates as well as ASICs (Dataquest 1988, 135-137). CMD represents a typical case of fraud with a dozen or more accounting tricks, including fictitious sales and fictitious revenue recognition (one-third of the company's $\$ 45$ million in revenue in 1994 was spurious) (Securities Exchange Commission 1999; MacDonald 2000; Jones 2011).
} 
The Spanish market was of a similar size to the Austrian, each covering around one quarter of the size for the total group, with the majority of users coming from consumer, telecom, and EDP segments (European Semiconductor Consumption History and Forecast 1985-1995). In this country, the socialist government in office, after a period of conservative inertia, conceived plans to boost production and research activities with the aim of incorporating the country into the mainstream of the electronic revolution and empowering the economy to gain competitiveness. This was done by segmenting the market according to technological level. In this way, moving towards cutting-edge plans entailed associating with multinational technology leaders, while for less sophisticated technology it resorted to national technological partners. The company (the phone monopoly), facing the challenge of inevitable technological change, situated itself at the forefront of initiatives in the field of microelectronics. Personalities and associations in the sector had been pushed in the same direction with little success.

The convergence of all the efforts resulted in a general action plan (Plan Electrónico e Informático Nacional: PEIN) and concrete business projects. The largest meant attracting investment and technology from the US multinational giant ATT in a joint venture called ATT Microelectrónica de España, with factory and research facilities located in Spain, an unusual practice for ATT. Both the CTNE as a pioneer in the introduction of microelectronics and a natural client of the products and the state as the 'sector lever' contributed financial resources, support, and infrastructure to make the most advanced company in highly sophisticated integrated circuits possible (Calvo 2016; Majó 1997).

This was not the only initiative of CTNE in the sector; rather, it combined this joint venture with others with different characteristics. According to one of the protagonists, CTNE used its 
huge purchasing and investment power to make industrial policy. Unlike the path adopted in general, in the case we examine now (European Silicon Structures), CTNE used its purchasing power as a tool for international collective action. ${ }^{36}$

\section{Demand as a tool for collective action: CTNE}

CTNE was a key enterprise in the national economy due to the considerable figures it presented in terms of customers that it had as subscribers (8.5 million) or users (several million), employment (61.500), and sales (380,000 billion pesetas). Its decisive weight also stemmed from its large annual investments $(180,000$ million pesetas) and its net fixed assets of 1.3 trillion pesetas (Morán and Lada 1984).

The semi-public Spanish monopoly launched a four-year plan that intended to restructure the industry and telecommunications services with a colossal investment of some 800,000 million pesetas, half of which was earmarked for the telephone network. Quantitative growth joined with the modernization of equipment with electronic and semi-electronic technology and the beginning of the adoption of optical fibre. ${ }^{37}$

The CTNE investment plan emerged almost in parallel to, but independently of, PEIN, which was the result of unprecedented joint planning with the government. Still backing innovation, it supported technology overlap (soft modernization) as a way to curb unemployment, immediate colonization by multinationals, and the inability of workers to absorb new technologies (Comparecencia, DSCD, 10/10/1984, 6.498-6.526). In this context, partnerships with companies possessing knowledge seemed unavoidable. Because of the implementation

\footnotetext{
${ }^{36}$ Conversation with Luis Solana, Madrid, March 8, 2016.

${ }^{37}$ More than two million urban lines and links equivalent to about 700,000 lines; $56 \mathrm{~km}$ of optical fibre: El País, October 23, 1983.
} 
of the plan, effective investment by the CTNE in 1985 almost doubled compared to the previous year. ${ }^{38}$

On 26 December, Telefonica joined the initial group of seven high-tech companies involved in European Silicon Structures to develop and manufacture a type of integrated circuit and to place that high-technology product within reach of small businesses. The other members of the group were Bosch, British Aerospace, Olivetti, Saab Scania, Bull, Philips, and Brown Boveri. ${ }^{39}$ These partners were customers and providers of information on markets and technology at the same time as being recipients of training in the potential applications of ES2 products. They joined in on all three major strategic goals, perhaps the most important of which was that ES2 products and technology would serve as catalysts for innovation in the long term. The investment was also geared towards profitability and access to a manufacturing facility working with state-of-the-art silicon at low cost and risk levels. ${ }^{40}$ Telefonica was the only telecommunications firm in this European-labelled group, due to its foundation, headquarters, research centre, and factory.

Telefonica entered the pan-European company ES2 with 5 per cent, the maximum amount of the project's participants, in order to prevent any further pressures. ${ }^{41}$ When it came to

\footnotetext{
${ }^{38}$ The Telefónica Group, 1985, 40.

${ }^{39}$ Le Monde, December 28, 1985. Some sources excluded Bosch, specified as a member Saab-Scania Combitech, an electronics subsidiary of the Swedish automotive and aerospace group, and added Advent, a capital risk firm. British Aerospace regarded the European Silicon Structures venture as an important new approach to European collaboration in a vital high technology industry: British Business 20, 1986, 3.
}

${ }^{40}$ MBDoT, December 18, 1985; Telefónica, Memoria: Balance Social 1984-1985, 156. This type of CMOS custom integrated circuit technology in short series fits exactly to the customer's needs to help increase competitiveness by shortening development time, increasing functionality and performance, and reducing costs; the North American press greeted it as the new wave of European industry: The New York Times, August 1, 1988. Custom chips met the same needs as a tailor-made suit (Cane 1987, 37).

${ }^{41}$ PRS Report Science \& Technology, November 8, 1985, 40. Telefonica contributed \$2.5 million and owned 45,000 shares of the total in the hands of Spanish partners, which also included major banks (Banesto, Bilbao, 
presenting it in the Spanish market, Telefonica emphasized that the new firm was intended to serve the custom circuits market and to manufacture prototypes in Europe with time-frames and prices that were lower than existing prototypes. The role of Telefonica was summarized in its acting as guardian to the introduction of these components into Spain through Comelta y Semiconductores S. A., specialized in the distribution and marketing of electronic components. On the other hand, Telefonica would provide technical advice to both companies, complete design requests, and provide appropriate training courses.

Table 3. Comparative view of ATT Microelectrónica de España and ES2 profiles

\begin{tabular}{ll|l}
\cline { 2 - 3 } City/Country & ATT Microelectrónica de España & \multicolumn{1}{c}{ ES2 } \\
\cline { 2 - 3 } Products & CBIC* $*$ customs & Rousset, France \\
\hline Process technology & CMOS M2 & CBIC, Arrays, Custom mil \\
\hline Min. line width & 1.25 & CMOS M2 \\
\hline Wafer size & 6 & 0.8 \\
\hline Max. wafer capacity & 14,000 & 5 \\
\hline S. Q. in start capacity (4wks.) & 383,320 & 1,000 \\
\hline Cleanroom (square feet) & 25,000 & 19,020 \\
\hline Cleanroom class & 1 & 0 \\
\hline Origin of owner & USA & 10 -ene \\
\hline Market structure & Merchant & Pan-European \\
\hline
\end{tabular}

* CBIC: Cell-Based Integrated Circuits: An ASIC device that is customized using a full set of masks and which uses automatic placement of cells and automatic routing.

Source: Compiled by author using European Fab Database

Hispano, Santander, and Urquijo-Unión): MBDoT, November 26, 1986. The press reduced the contribution of Spain to 4 per cent: El País, November 19, 1986. 
From a comparative perspective, the involvement of Telefonica in ATT Microelectrónica de España and ES2 presents several important differences. The more purely technical, contained in Table 3, indicate that they did not compete in the same market since ES2 relied on short series and ATT on long series. ${ }^{42}$ Other very notable differences are related to the scale, the nature of the alliance, the form of financing, the role of Telefonica in the joint venture, and the territorial expression of the initiative. AT\&T Microelectrónica de España resulted from a bilateral agreement between the semi-public monopoly Telefonica and the multinational AT\&T under the significant political guidance of the governments for several reasons, including economic and geostrategic reasons. Unlike what happened with ES2, the Spanish government helped Microelectrónica de España with numerous grants, financial and fiscal resources, as well as with infrastructures as a counterpart to the location of the firm's productive activity and its taxation in Spanish territory. Microelectrónica de España was a case of attraction of FDI over export capital, which was the case of ES2. An integrated market for ES2 and Spanish domestic and international markets for MEdE were the formulas adopted. Telefonica's role in the project was subordinate despite the apparent equality of participation, judging from the almost total absence of nationals in the management of ES2. ${ }^{43}$ MEdE was a joint venture with unequal participation from the partners and, therefore, with differing levels of control over the company among members.

\footnotetext{
${ }^{42}$ This feature was stressed in Le Monde, December 28, 1985.

${ }^{43}$ As an exception, Carlos A. López Barrio was chairman of the Strategic Partners Committee of ES2 and a member of the Board of Directors. López Barrio is a professor of Electronics Technology at the Universidad Politécnica de Madrid (UPM) and director of the Integrated Systems Laboratory (Department of Electronics Engineering) (Kabene 2010, 344).
} 
Table 4. Top 10 World Digital MOS CBIC

\begin{tabular}{lrrrr} 
& \multicolumn{3}{c}{ Revenue (\$Million) } & Ranking \\
\cline { 2 - 6 } \multicolumn{1}{c}{ Suppliers by revenue } & \multicolumn{2}{c}{1988} & 1989 & 1989 \\
\hline VLSI Technology & 15 & 22 & 29 & 1 \\
\hline Austria Mikro Systeme & 13 & 16 & 24 & 2 \\
\hline Texas Instruments & 5 & 12 & 24 & 3 \\
\hline European Silicon Structures & 6 & 12 & 17 & 4 \\
\hline MEDL & 5 & 11 & 17 & 5 \\
\hline Siemens & 15 & 15 & 17 & 6 \\
\hline SGS-Thomson & 2 & 3 & 15 & 7 \\
\hline AT\&T & 6 & 9 & 10 & 8 \\
\hline Harris Semiconductor & 4 & 8 & 10 & 9 \\
\hline Honeywell/Atmel & 0 & 0 & 10 & 10 \\
\hline
\end{tabular}

Source: Dataquest, January 1991

Graph 2. Top 10 Digital MOS CBIC Suppliers by revenue

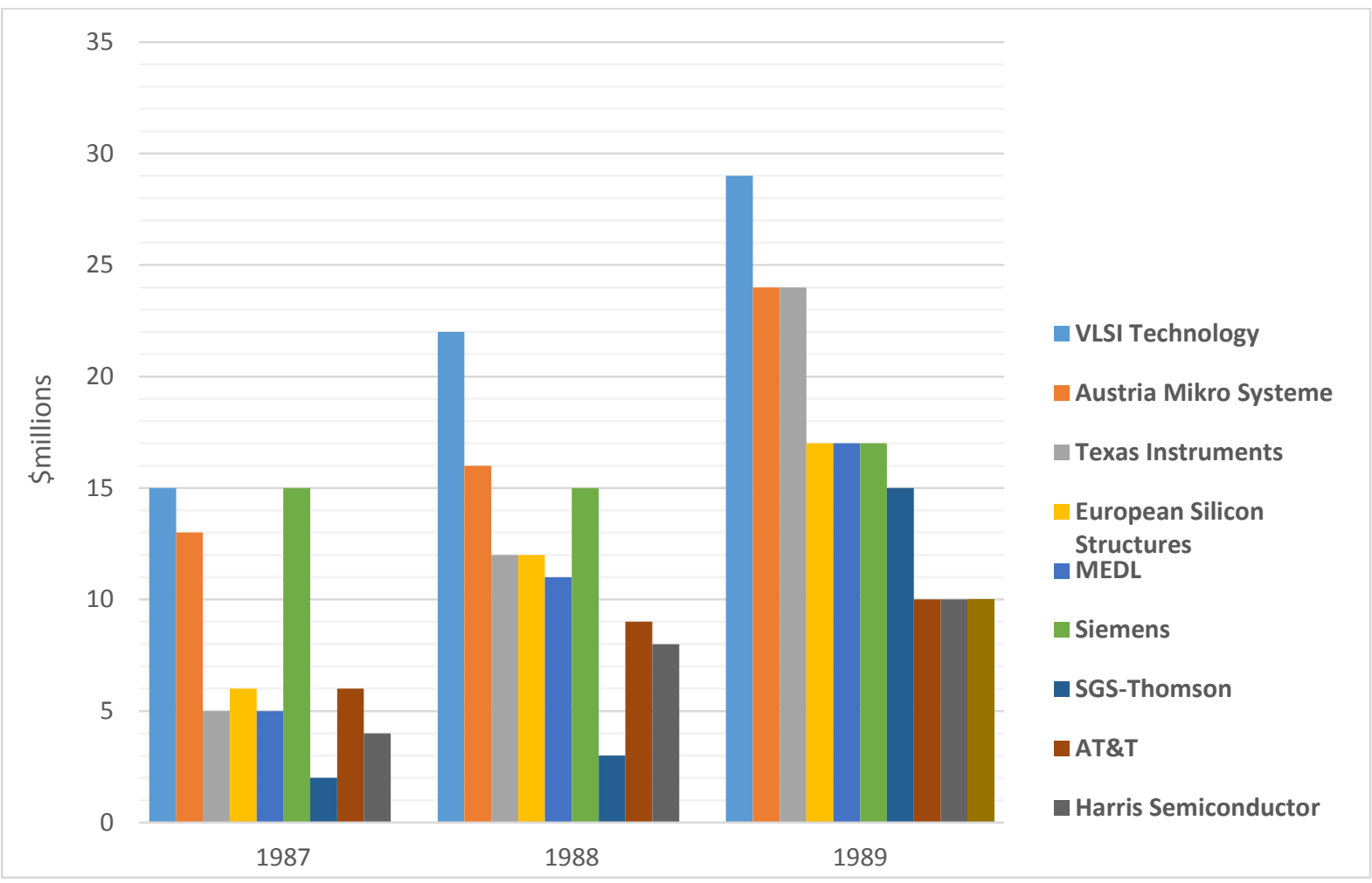

Source: Own from Dataquest January 1991) 
Table 5. Total MOS CBIC suppliers by revenue (\$Million)

\begin{tabular}{lrrrc} 
& \multicolumn{3}{c}{ Revenue (\$Million) } & Ranking \\
\cline { 2 - 5 } \multicolumn{1}{c}{ Suppliers by revenue } & 1987 & 1988 & 1989 & 1989 \\
\hline Mietec & 27 & 29 & 34 & 1 \\
Texas Instruments & 5 & 12 & 30 & 2 \\
VLSI Technology & 15 & 22 & 29 & 3 \\
Austria Mikro Systeme & 15 & 19 & 27 & 4 \\
MEDL & 5 & 12 & 19 & 5 \\
SGS-Thomson & 2 & 3 & 19 & 6 \\
European Silicon Structures & 6 & 12 & 17 & 7 \\
Siemens & 15 & 15 & 17 & 8 \\
IMP Europe & 2 & 7 & 11 & 9 \\
LSI Logic & 4 & 7 & 11 & 10 \\
Source: Dataquest Annuary 1991 & & & &
\end{tabular}

\section{Conclusion}

European governments eager to promote competitive industries in their respective countries, corporate elites, and the voracity of capital joined forces in high-tech industrial projects in the framework of the creation of a single market. Without a doubt, one of the most representative cases was ES2, a panEuropean initiative in the field of microelectronics and semiconductors. Results were far from the ambitions of the initial plans, but quite possibly left traces in the configuration of differential features of the European industry with regard to the North American and the Japanese industries. In the margins of the central axis of the project, Spain played the role of secondary participant through the involvement of the CTNE, the telecommunications monopoly very soon to disappear to conform to Community rules. CTNE in general used its purchasing and investment power as a tool for industrial policy but in the case we have surveyed (European Silicon Structures), CTNE used its purchasing power as a means for a new supply source and for collective international action. 


\section{Acknowledgments}

Financial support has been received from the Spanish Ministerio de Economía y Competitividad, research project HAR2013-41453-P.

\section{Primary sources}

INI Historical Archive, Madrid.

Securities Exchange Commission, US.

Telefonica, Minutes of the Board of Directors, Madrid.

Telefonica, Minutes of the Steering Committee, Madrid.

\section{Oral sources}

Computer History Museum, Mountain View, USA.

Juan Mulet Melià, conversation with the author, Barcelona.

Luis Solana, conversation with the author, Madrid, March 8, 2016.

Oral History of Pasquale Pistorio Interviewed by Doug Fairbairn.

\section{References}

Bonno, G. 1986. "Des puces sur mesure.” Electronics 59 on-line.

Brooke, Peter A., and Daniel Penrice. 2009. A Vision for Venture Capital: Realizing the Promise of Global Venture Capital and Private Equity. Boston: UPNE.

Calvo, Angel. 2014. Standard Eléctrica y la industria de las telecomunicaciones en España, 18771975. Barcelona: Ariel.

Campbell, Katharine. 2003. Smarter Ventures: A Survivor's Guide to Venture Capital. London: Pearson Education.

Cane, Alan. 1987. "ES2 Moves Bespoke Chips Towards Off-the-Peg Prices.” Financial Times, June 10.

Collins, Timothy, and Thomas L. Doorley. 1994. Teaming Up for the '90s: A Guide to International Joint Ventures and Strategic Alliances. Homewood IL: McGraw-Hill School Education Group.

Cowhey, Peter F., and Jonathan D. Aronson. 1993. Managing the world economy: the consequences of corporate alliances. New York: Council on Foreign Relations Press.

Dataquest. 1988. A decade of semiconductor companies. San José: Dataquest.

Dataquest. 1989. Worldwide Semiconductor Companies. San José: Dataquest.

Dataquest. 1990. European semiconductor consumption forecast 1983-1995. San José: Dataquest.

Dataquest. 1991. Semiconductors Europe. San José: Dataquest. 
Dunning, John H. 2001. "The eclectic (OLI) paradigm of international production: Past, present and future." International Journal of the Economics of Business 8 (2): 173-190.

Dodgson, Mark, ed. 1989. Technology Strategy and the Firm: Management and Public Policy. New York: Longman.

ESPRIT. 1991. Progress and results 1990/91. Luxembourg: Commission of the European Communities.

Faulhaber, Gerald R., and Gualtiero Tamburini. 2012. European Economic Integration: The Role of Technology. New York: Springer.

Fletcher, André. 2013. Profile of the Worldwide Semiconductor Industry: Market Prospects to 1997. Oxford: Elsevier.

Forester, Thomas. 1989. High-Tech Society: The Story of the Information Technology Revolution. Cambridge, MASS: MIT Press.

Forsgren, Mats. 2013. Theories of the Multinational Firm: A Multidimensional Creature in the Global Economy. Cheltenham: Edward Elgar.

Friend, Julius W. 1998. The Long Presidency: France in the Mitterrand Years, 1981-1995. Boulder, CO: Westview Press.

Guile, Bruce R. 1987. Technology and Global Industry: Companies and Nations in the World Economy. Washington: National Academies Press.

Hill, Charles W. L., Gareth R. Jones, and Melissa A. Schilling. 2016. Strategic Management: Theory: An Integrated Approach. Boston, MA: Cengage Learning.

Johanson, Jan, and Jan-Erik Vahlne. 2009. "The Uppsala internationalization process model revisited: From liability of foreignness to liability of outsidership." Journal of International Business Studies 40 (9): 1411-31.

Jones, Phil L., and Anne Buckley. 1989. Electronics Computer Aided Design. Manchester: Manchester University Press.

Jones, Michael J. 2011. Creative Accounting, Fraud and International Accounting Scandals. Chichester: John Wiley \& Sons.

Kabene, Stéfane M. 2010. Human Resources in Healthcare, Health Informatics and Healthcare Systems. New York: Idea Group Inc.

Kassim, Hussein, and Anand Menon, eds. 2002. The European Union and National Industrial Policy. London: Routledge.

Klincewicz, Krzysztof. 2005. Strategic Alliances in the High-tech Industry. Berlin: Logos Verlag. Leuenberger, Theodor, and Martin E. Weinstein. 2012. Europe, Japan and America in the 1990s: Cooperation and Competition. Berlin: Springer. 
Lipnack, Jessica, and Jeffrey Stamps. 1993. The TeamNet Factor: Bringing the Power of Boundary Crossing Into the Heart of Your Business. Essex: Wiley.

MacDonald, Elizabeth. 2000. "Regulators seek to penalize auditors who missed fraud." Wall Street Journal, February 19.

Majó, Joan. 1997. Chips, cables y poder. Barcelona: Planeta.

Marchipont, Jean-François. 1997. La stratégie industrielle de l'Union européenne. Conséquences et enjeux. Paris: Éditions Continent Europe.

Meister, Jeanne C. 2001. Building a learning organization: 7 lessons to involve your CEO. San José: iUniverse.

Morán, José Manuel, and Luis Lada. 1984. “Los planes de Telefónica.” El País, May 2.

Mytelka, Lynn Krieger. 1990. Strategic Partnerships: States, Firms, and International Competition. London: Pinter.

Pouderoux, Noël. 1968. "La micro-électronique européenne face aux Etats-Unis." Le Monde diplomatique, December 22.

Sandholtz, Wayne. 1992. High-Tech Europe: The Politics of International Cooperation. Berkeley: University of California Press.

Robin, Saxby. Interview with Dane Elliot and Doug Fairbairn. Oral History of Sir Robin Saxby. Mountain View, California, October 16, 2012.

Smidt, Marc, and Egbert Wever. 2012. The Corporate Firm in a Changing World Economy: Case Studies in the Geography of Enterprise. Abingdon: Routledge.

Thakur, Manab, Gene E. Burton, and B. N. Srivastava. 1997. International Management: Concepts and Cases. New Delhi: McGraw-Hill.

US Congress. 1991. Competing economies: America, Europe, and the Pacific Rim. Washington: DIANE Publishing.

Vasudeva, P. K. 2006. International Marketing. New Delhi: Excel Books.

Wedgwood, C. G., ed. 2013. European Electronics Directory 1994: Systems and Applications. Oxford: Elsevier.

Yin, Robert K. 1993. Applications of case study research. Applied Social Research Series, Vol. 34. London: Sage. 
Annex 1. Board of directors of European Silicon Structures, 1988

\begin{tabular}{llll}
\hline \multicolumn{1}{c}{ Name } & \multicolumn{1}{c}{ Position } & \multicolumn{1}{c}{ Prior firm } & \multicolumn{1}{c}{ Prior Position } \\
\hline J.L. Grand-Clement & CEO/MngDir & Motorola & VP Europe Group \\
\hline Pierre Lesieur & VPFin/Admin & Motorola & Dir Finance \\
\hline Rod Attwooll & VP/DirOps & Texas Instrument & Mng Dir Bedford \\
\hline Bernard Pruniaux & VP/Mfg & Thomson CSF & Dir Opns \\
\hline John Gray & VP/DirS/ WTech & Lattice Logic & Founder/Mng Dir \\
\hline J.P. Demange & VP/DirS.Europe & National & Dir Strat Mktg \\
\hline H.P. Friedrich & VP/DirCentra Europe & N/A & Mng Dir \\
\hline Francis Courrèges & WfrFabMgr & Sierra Semicond & Prod Eng Mgr \\
\hline Eric Demoulin & DirTechnology & Thomson CSF & Dir MOS Tech \\
\hline
\end{tabular}

Source: Compiled by author using Dataquest, June 1988, p. 205.

Annex 2. Participants in the Technology Initiative in BiCMOS for Applications (TIBIA)

Companies

ALCATEL BELL MANUFACTURING COMPANY, Belgium; ALCATEL SEL AG, Germany; GEC Plessey Semiconductors PLC, United Kingdom; PHILIPS CONSUMER ELECTRONICS B.V., Netherlands; SGS THOMSON MICROELECTRONICS SA, France; SGS-Thomson Microelectronics SrL, Italy; SIEMENS AG, Germany; Semiconductores Investigación y Diseño, Tres Cantos Spain; TELEFONICA I+D, Spain; TEMIC TELEFUNKEN MICROELECTRONIC GMBH, Germany.

\section{Scientific institutions}

CENTRO NACIONAL DE MICROELECTRONICA, BELLATERRA, Spain; Centre National d'Études des Télécommunications (CNET), France; Commissariat à l'Energie Atomique (CEA), France; Centre d'Études de Grenoble, France; DELFT INSTITUTE OF MICROELECTRONICS \& SUBMICRONTECHNOLOGY, Netherlands; ÉCOLE POLYTECHNIQUE FEDERALE DE LAUSANNE, Switzerland; INDUSTRIAL MICROELECTRONICS CENTER, Sweden; INSTITUTO DE ENGENHARIA DE SISTEMAS E COMPUTADORES, Portugal; Inter-University Microelectronics Center, Belgium; LINKOEPING UNIVERSITY, Sweden; NATIONAL 
TECHNICAL UNIVERSITY OF ATHENS, Greece; NMRC, University College Cork, Ireland; SIEMENS ENTWICKLUNGSZENTRUM FUER MIKROELEKTRONIK, Austria; TECHNICAL RESEARCH CENTRE OF FINLAND, Finland; TECHNISCHE UNIVERSITAET BERLIN, Germany; TECNOPOLIS CSATA NOVUS ORTUS; UNIVERSITY OF CATANIA, Italy; UNIVERSITY OF DUBLIN, Ireland; SCRL, Italy.

Source: CORDIS June 21, 1994. 